\title{
Antibacterial activity and sensory properties of Heracleum persicum essential oil, nisin, and Lactobacillus acidophilus against Listeria monocytogenes in cheese
}

\author{
A. Ehsani ${ }^{1}$, A. Rezaeiyan ${ }^{2}$, M. Hashemi ${ }^{3}$, M. Aminzare ${ }^{4}$, B. Jannat ${ }^{5}$ and A. Afshari ${ }^{3}$
}

1. Department of Food Science and Technology, Faculty of Nutrition, Tabriz University of Medical Sciences, Tabriz, Iran; 2. Department of Food Hygiene and Aquatics, Faculty of Veterinary Medicine, Urmia University, Urmia, Iran; 3. Department of Nutrition, Faculty of Medicine, Mashhad University of Medical Sciences, Mashhad, Iran; 4. Department of Food Safety and Hygiene, School of Public Health, Zanjan University of Medical Sciences, Zanjan, Iran; 5. Halal Research Center of IRI, FDA, Tehran, Iran.

Corresponding author: A. Afshari, e-mail: asmafshr@gmail.com

Co-authors: AE: ehsani@tbzmed.ac.ir, AR: rezayianA@gmail.com, MH: hashemimd@mums.ac.ir, MA: m.aminzare@zums.ac.ir, BJ: janatbhr@sina.tums.ac.ir

Received: 02-07-2018, Accepted: 20-11-2018, Published online: 17-01-2019

doi: 10.14202/vetworld.2019.90-96 How to cite this article: Ehsani A, Rezaeiyan A, Hashemi M, Aminzare M, Jannat B, Afshari A (2019) Antibacterial activity and sensory properties of Heracleum persicum essential oil, nisin, and Lactobacillus acidophilus against Listeria monocytogenes in cheese, Veterinary World, 12(1): 90-96.

\section{Abstract}

Aim: The aim of this study was to evaluate the antibacterial and chemical effect of Heracleum persicum essential oil (EO), nisin, Lactobacillus acidophilus, and their combination against Listeria monocytogenes both in vitro and in Iranian white cheese model.

Materials and Methods: Chemical compositions of $H$. persicum EO were analyzed by gas chromatography-mass spectrometry. After production of Iranian white cheese, minimum inhibitory concentration (MIC) and minimum bactericidal concentration of EO and nisin and agar spot test of L. acidophilus against L. monocytogenes were evaluated.

Results: Hexyl butanoate (25.98\%), octyl isobutyrate (17.82\%), methyl butyrate (14.37\%), and pentyl cyclopropane $(12.77 \%)$ were the main components of the EO. MIC of the EO against L. monocytogenes was $2.5 \mathrm{mg} / \mathrm{mL}$. Combination of nisin $(5.3 \mathrm{IU} / \mathrm{mL})$ and $H$. persicum EO $(2500 \mu \mathrm{g} / \mathrm{mL})$ showed increasing effect against L. monocytogenes (fractional inhibitory concentration $=0.9)$, while a higher concentration of EO and nisin showed undesirable effect on the cheese flavor. Furthermore, a combination of $10^{12} \mathrm{CFU} / \mathrm{g}$ L. acidophilus with H. persicum EO at the concentration of $2.5 \mathrm{mg} / \mathrm{mL}$ (T12) showed acceptable sensorial and also antibacterial results in Iranian white cheese.
\end{abstract}

Conclusion: Combination of H. persicum EO, L. acidophilus, and nisin can be recommended as natural preservatives and flavoring agents in cheese.

Keywords: Heracleum persicum, Lactobacillus acidophilus, Listeria monocytogenes, Nisin.

\section{Introduction}

Today, people are more willing to consume foods with natural preservatives so-called green rather than with artificial preservatives [1]. Natural preservatives such as essential oils (EOs) are produced from some seasonings and herbs and have flavor enhancing and antimicrobial effects [2]. EOs are oily aromatic liquid(s), obtained from different parts of plants which are also called ethereal oils or volatile oils [3]. Heracleum persicum (Persian Hogweed or Golpar) is a plant which has been used in the preparation of food and medicine in Iran. The fruits and leaves of $H$. persicum are used to flavor pickles. It is also used as an antiseptic, analgesic, anti-flatulence, and digestive aid

\footnotetext{
Copyright: Ehsani, et al. Open Access. This article is distributed under the terms of the Creative Commons Attribution 4.0 International License (http://creativecommons.org/licenses/by/4.0/), which permits unrestricted use, distribution, and reproduction in any medium, provided you give appropriate credit to the original author(s) and the source, provide a link to the Creative Commons license, and indicate if changes were made. The Creative Commons Public Domain Dedication waiver (http://creativecommons.org/ publicdomain/zero/1.0/) applies to the data made available in this article, unless otherwise stated.
}

in Iranian traditional medicine [4]. It is noteworthy that, due to the impact of geographical climate on the components of $H$. persicum, there are various reports about chemical and, especially, anti-bacterial properties of some parts of this herb [5].

Nisin is a known antimicrobial agent and the only bacteriocins used as an additive to increase the shelf life of food in industries of $>50$ countries [6]. Combination of herbal EOs and extracts with nisin shows a synergistic effect on decreasing extracellular adenosine triphosphate in microorganisms [7]. On the other hand, the use of probiotics to enhance health and improve the digestive system has been proposed for decades. The probiotic bacteria (especially, different species of Lactobacillus and Bifidobacterium) are known to possess antimicrobial activity, and therefore, they can be used to control and prevent the growth of spoilage bacteria and food-borne pathogens instead of chemical and synthetic preservatives [8].

Hence, this study was conducted to determine the following: (1) The chemical composition and antimicrobial properties of the aerial parts of the H. persicum EO collected from the mountainous region in 
Northeastern of Iran, (2) in vitro antibacterial effect of H. persicum EO, nisin, and Lactobacillus acidophilus against Listeria monocytogenes, and (3) antimicrobial activity of $H$. persicum EO, L. acidophilus, and nisin against $L$. monocytogenes in Iranian white cheese.

\section{Materials and Methods}

\section{Ethical approval}

This study does not work on human or animal so, it does not need ethical approval.

\section{Preparation and analysis of the EO}

Aerial parts of the $H$. persicum plant were collected in full flowering stage in July 2014 from the mountainous regions: Sheykh Musa and Bandpei, Babol County, Mazandaran Province, Iran. They were kept away from sunlight at room temperature until completely dried before distillation [9]. Distillation operation was carried out by Clevenger Apparatus according to the method of water distillation. The extracted EOs were stored in dark glass container(s) in a refrigerator $\left(4^{\circ} \mathrm{C}\right)$ for chemical and antimicrobial analysis [10].

Constituents of the $H$. persicum EO were determined by gas chromatography (GC) device (Agilent Technologies-7890A model) connected to mass spectrometry (MS) (Agilent Technologies-5975C model) with HP-5MS capillary column of $30 \mathrm{~m}$ (inner diameter of $0.25 \mathrm{~mm}$ and inner layer thickness of $0.25 \mu \mathrm{m}$ ). The initial temperature was set up at $60-280^{\circ} \mathrm{C}$ with a gradual increase of $4^{\circ} \mathrm{C}$. The injection chamber temperature was $250^{\circ} \mathrm{F}$ and helium gas was used at a rate of $2 \mathrm{~mL} / \mathrm{min}$. Ionization energy parameters and temperature of ionization source were $70 \mathrm{eV}$ and $270^{\circ} \mathrm{C}$, respectively [11]. Separated chemicals were identified from their corresponding mass spectra using data available in the Wiley Library (Wiley-VCH 2001 data software, Weinheim, Germany).

\section{Bacterial preparation}

The lyophilized cultures of $L$. monocytogenes PTCC1165 were transferred into brain heart infusion (BHI) broth (Merck, Germany) and incubated at $37^{\circ} \mathrm{C}$ for $18 \mathrm{~h}$, with two consecutive transfers. Bacterial suspension was added to sterile cuvettes containing $5 \mathrm{~mL}$ of BHI broth, and the absorbance was determined at $600 \mathrm{~nm}$ using a spectrophotometer until achieving the concentration of $1.5 \times 10^{8} \mathrm{CFU} / \mathrm{mL}$ (according to the $0.5 \mathrm{McF}$ arland standard turbidity) and serially diluted to the desired concentration $\left(1.5 \times 10^{6} \mathrm{CFU} / \mathrm{mL}\right)$. The suspension was used for the inoculation of BHI agar or cheese samples.

\section{Nisin preparation}

Amount of $10 \mathrm{~g}\left(10^{6} \mathrm{IU} / \mathrm{g}\right)$ of pure $2.5 \%$ nisin (balance sodium chloride) (Sigma-Aldrich Inc., United Kingdom), from Lactococcus lactis, was dissolved in hydrochloric acid $0.02 \mathrm{~N}$ to reach $10^{5} \mathrm{IU} / \mathrm{mL}$. Then, it was sterilized using a $0.45 \mu \mathrm{m}$ filter (Millex-HV Syringe Filter Unit) and was frozen at $-20^{\circ} \mathrm{C}$. The stock solution of nisin was thawed to $25^{\circ} \mathrm{C}$ and diluted in sterile water to obtain the desired concentrations for further analysis in vitro and in Iranian white cheese.

\section{Probiotic preparation}

Lyophilized L. acidophilus (PTCC 1643) was prepared from Iranian Research Organization for Science and Technology. It was cultured on ManRogosa-Sharpe (MRS) broth under sterile condition and incubated anaerobically at $37^{\circ} \mathrm{C}$ for $24-48 \mathrm{~h}$ to achieve the desired bacterial count $\left(10^{9}\right.$ and $\left.10^{12}\right)$. The microbial cells were harvested and washed twice with sterile peptone water $(0.1 \%)$ for inoculation into milk.

\section{In vitro antibacterial properties of $H$. persicum EO against $L$. monocytogenes}

Antibacterial activity of $H$. persicum EO was evaluated against L. monocytogenes, using two methods: Microdilution and disk diffusion. For disk diffusion method, the amount of $100 \mu \mathrm{l}$ of $1.5 \times 10^{6}$ $\mathrm{CFU} / \mathrm{mL}$ of bacterial suspension was cultured on $\mathrm{BHI}$ agar. Then, paper discs with a diameter of $6 \mathrm{~mm}$ were placed on each plate by sterile forceps. A concentration of $10 \mathrm{mg} / \mathrm{mL}$ of the EO was also prepared with methanol solvent. Then, $10 \mu \mathrm{l}$ of the EO was spilled on each disk and incubated for $24 \mathrm{~h}$ at $37^{\circ} \mathrm{C}$. Finally, the diameter of inhibition zone around each disk was measured by a caliper. Antibiotics discs (ampicillin) were used as positive control [12].

Minimum inhibitory concentration (MIC) and minimum bactericidal concentration (MBC) values were also determined by microdilution method using 96-well microplates. The EO was prepared at the highest concentration $(80 \mathrm{mg} / \mathrm{mL})$ by dimethyl sulfoxide (10\%) solvent, and the serial two-fold dilutions were made in the concentration range from 0.31 to $80 \mathrm{mg} / \mathrm{mL}$ in nutrient broth. Then, $160 \mu \mathrm{L}$ of BHI broth, $20 \mu \mathrm{L}$ of bacterial suspension at concentration of $1.5 \times 10^{6} \mathrm{CFU} / \mathrm{mL}$, and $20 \mu \mathrm{L}$ of the $\mathrm{EO}$ (the final volume of each well: $200 \mu \mathrm{L}$, the final concentrations of the EO: $0.03-8 \mathrm{mg} / \mathrm{mL}$, and the final bacterial level: $\sim 1.5 \times 10^{5} \mathrm{CFU} / \mathrm{mL}$ ) were poured into the wells. Controls (without the addition of bacteria and without addition of the EO) were also prepared. Microplates were shacked at $2500 \mathrm{rpm}$ for $30 \mathrm{~s}$ and kept at $37^{\circ} \mathrm{C}$ for $24 \mathrm{~h}$. The lowest EO concentration that prevented bacterial growth (no visible bacterial growth) was considered as MIC value. To determine $\mathrm{MBC}$ value, $5 \mathrm{~mL}$ from wells with no visible growth in the MIC experiment was inoculated on BHI agar. The lowest concentration of the $\mathrm{EO}$ with bactericidal effects (lack of growth on the BHI agar) was considered as MBC value $[10,12,13]$.

\section{In vitro antibacterial activity of $L$. acidophilus and} nisin against $L$. monocytogenes

Agar spot test was used to evaluate the antimicrobial activity of L. acidophilus against mentioned pathogenic strain. L. acidophilus colonies that had been grown on MRS agar (Merck, Darmstadt, Germany) were inoculated on BHI agar 
containing $20 \mathrm{mM}$ glucose and incubated at $37^{\circ} \mathrm{C}$ for $24 \mathrm{~h}$ under anaerobic condition (Anaerobic jar BBL, Cockeysville, Maryland, USA). After incubation, spots were transferred to the soft agar plates (BHI, 2\% glycerol and $0.7 \%$ agar), which had been previously inoculated with $100 \mu \mathrm{l}$ of $1.5 \times 10^{6} \mathrm{CFU} / \mathrm{mL}$ of bacterial suspension. After $1 \mathrm{~h}$ at $37{ }^{\circ} \mathrm{C}$ in aerobic conditions, the plates were incubated for another $18-24 \mathrm{~h}$ at the aerobic condition, and the diameter of inhibition zone was measured by a caliper. Inhibition zones with a diameter of $1 \mathrm{~mm}$ or more were recorded as positive results [14].

Nisin with concentrations of $100,200,300,400$, $500,800,1000,1500$, and $2000 \mathrm{IU} / \mathrm{mL}$ in tryptic soy broth was prepared, and the microdilution assay was performed as previously described.

\section{In vitro antibacterial effect of combination use of the EO and nisin against $L$. monocytogenes}

To assess the combined effects of nisin and the EO, fractional inhibitory concentration (FIC) value was used [15] as follows: Eight concentrations (five concentrations less than the MIC value, one equal with the MIC value, and two concentrations more than the MIC value) of $H$. persicum EO and nisin were prepared according to the microdilution method. Then, $140 \mu \mathrm{l} \mathrm{BHI}$ broth, $20 \mu \mathrm{l}$ of bacterial suspension (final dose in each well: $\left.1.5 \times 10^{5}\right), 20 \mathrm{~mL}$ of the EO concentrations, and $20 \mu \mathrm{l}$ of nisin concentrations were poured into each well. The microplates were shaken for $30 \mathrm{~s}$ at $2500 \mathrm{rpm}$ and incubated at $35^{\circ} \mathrm{C}$ for $24 \mathrm{~h}$. Then, the MIC values of the $\mathrm{EO}$ and nisin were determined, and the FIC value was calculated using the following equation:

FIC of antibacterial substances $=$ Combination $\mathrm{MIC} / \mathrm{MIC}$

FIC value (FIC index) $\leq 0.5$ indicates a synergistic effect, between 0.5 and 1 indicates an increased effect, between 1 and 4 indicates no effect, and $>4$ indicates an antagonistic effect [16].

Antimicrobial activity of the EO with $L$. acidophilus and nisin against $L$. monocytogenes in Iranian white cheese

\section{Production of Iranian white cheese}

Fresh cow milk was pasteurized at a temperature of $72 \pm 2^{\circ} \mathrm{C}$ for $15 \mathrm{~s}$ and was used for the production of Iranian white cheese. Desired dose of $10^{3} \mathrm{~L}$. monocytogenes per milliliter of BHI broth was added into each sterile container containing $5 \mathrm{~L}$ of milk at a temperature of $35^{\circ} \mathrm{C} .0 .5 \%$ of starter culture (Chr. Hansen R 704), including L. lactis subsp. cremoris and L. lactis subsp. diacetylactis, was added to the milk [17]. Three concentrations of L. acidophilus $\left(10^{9}\right.$ and $\left.10^{12}\right)$ nisin $(200$, 400 , and $800 \mathrm{IU} / \mathrm{mL})$ and the EO $(2.5,5$, and $10 \mathrm{mg} /$ $\mathrm{mL}$ ) were added to the milk samples according to the treatments in Table- 1 . Then, $0.02 \%$ of calcium chloride $\left(\mathrm{CaCl}_{2}\right)$ in $20 \mathrm{~mL}$ of distilled water was added and dissolved in the milk at $40^{\circ} \mathrm{C}$. To improve the efficiency of the rennet, the milk temperature was held at about $35^{\circ} \mathrm{C}$ during the clot formation. After $1 \mathrm{~h}$, the clot was cut into $1-2 \mathrm{~cm}$ cubic pieces, and it was rehydrated under the pressure of $10 \mathrm{~kg}$ for $6 \mathrm{~h}$, according to the Iranian white cheese preparation [17]. Then, rehydrated clots were kept in $22 \%$ brine $(\mathrm{w} / \mathrm{v})$ for $8 \mathrm{~h}$. Clots were then transferred into $12 \%$ sterile salt water and kept at $14-16^{\circ} \mathrm{C}$ for 15 days. Microbial (bacterial enumeration) and chemical (determination of dry matter, acidity, and fat) analyses were performed on days: 0 (immediately after inoculation of bacteria in milk), 3, 7, 15 (at the end of cheese ripening period at $14-16^{\circ} \mathrm{C}$ ), 30,45 , and 60 .

\section{Bacterial enumeration}

About $10 \mathrm{~g}$ of sample was placed in a sterile bag containing $90 \mathrm{~mL}$ of $0.1 \%$ sterile peptone water for homogenization using a Stomacher (Seward, London, UK). After serial dilutions preparation, Listeria selective agar (Merck) was used for surface colony counting at $37^{\circ} \mathrm{C}$ for $48 \mathrm{~h}$ [18]. It should be mentioned that the survivability of the probiotics was not evaluated in this study.

\section{Chemical analysis}

Moisture and dry matter content analysis were performed at the end of the study by drying the samples at $102 \pm 2{ }^{\circ} \mathrm{C}$ in an oven (Memmert, Schwabach, Germany), according to the following equation [19]:

$$
\mathrm{H}=\frac{\mathrm{x}-\mathrm{y}}{\mathrm{z}} \times 100
$$

Where H: \% Moisture; $\mathrm{x}$ : Weight of the container and sample before drying; $y$ : Weight of the container and sample after drying; and z: Sample weight;

Moisture content $=\%$ Dry matter- 100

Fat and protein contents were also determined by Gerber and Kjeldahl methods at the end of the study, respectively [18]. $\mathrm{pH}$ measurement was performed according to the method previously described by Sadler and Murphy [19] on days $0,3,7,15,30$, 45 , and 60 .

Table-1: Treatments containing EO, nisin, and L. acidophilus in Iranian white cheese.

\begin{tabular}{ll}
\hline Treatments & Concentrations \\
\hline T1-T3 & EO concentration $(2.5,5$, and $10 \mathrm{mg} / \mathrm{mL})$ against L. monocytogenes \\
T4 and T5 & L. acidophilus $\left(10^{9}\right.$ and $\left.10^{12} \mathrm{CFU} / \mathrm{mL}\right)$ against $L$. monocytogenes \\
T6-T8 & Nisin $(200,400$, and $800 \mathrm{IU} / \mathrm{mL})$ against $L$. monocytogenes \\
T9-T14 & L. acidophilus $\left(10^{9}\right.$ and $\left.10^{12} \mathrm{CFU} / \mathrm{mL}\right)+\mathrm{EO}(2.5,5$, and $10 \mathrm{mg} / \mathrm{mL})$ against $L$. monocytogenes \\
T15-T23 & Nisin $(200,400$, and $800 \mathrm{IU} / \mathrm{mL})+\mathrm{EO}(2.5,5$, and $10 \mathrm{mg} / \mathrm{mL})$ against $L$. monocytogenes \\
T24 & Control (without addition of nisin, EO, and L. acidophilus) \\
\hline
\end{tabular}

EO=Essential oil, L. acidophilus=Lactobacillus acidophilus, $L$. monocytogenes=Listeria monocytogenes 


\section{Sensory evaluation}

Sensory characteristics of the treatments were evaluated by 9 -point hedonic system by trained panelists who were selected from students and staff of the Department of Veterinary Medicine, Urmia University. Color, odor, texture, taste, and overall acceptability were evaluated on day 60 [20]. Treatments $(500 \mathrm{~g})$ containing different concentrations of the EO, probiotic, and nisin were prepared without inoculation of L. monocytogenes.

\section{Statistical analysis}

All experiments were performed in triplicate. Statistical analysis was performed with SPSS software (version 18.0; IBM, Armonk, USA). Repeated measure and ANOVA analysis were used for comparing results between different groups. $p<0.05$ was considered as statistically significant.

\section{Results}

\section{GC/MS analysis}

Chemical compositions of $H$. persicum EO were determined by GC connected to MS and are shown in Table-2. The main constituents of the EO were butanoic acid, hexyl ester (hexyl butanoic) $(25.98 \%)$, N-octyl 2-methyl butyrate (14.37\%), pentyl cyclopropane $(12.77 \%)$, and octyl isobutyrate (17.82\%).

\section{In vitro antibacterial properties of $H$. persicum EO,} nisin, and $L$. acidophilus

Results of in vitro antibacterial properties of H. persicum EO by disk diffusion method showed

Table-2: Chemical constituents of $H$. persicum EO analyzed by GC/MS.

\begin{tabular}{lcc}
\hline Compound & $\begin{array}{c}\text { Retention } \\
\text { time (min) }\end{array}$ & Amount (\%) \\
\hline Butanoic acid, butyl ester & 5.618 & 0.7 \\
Octanal & 5.608 & 0.97 \\
Isobutyl isovalerate & 5.894 & 0.27 \\
Hexyl acetate & 6.159 & 2.88 \\
(acetic acid and hexyl ester) & & \\
Isopropylbenzene & 6.381 & 1.47 \\
Butyl 2-methylbutyrate & 6.889 & 1.42 \\
Butanoic acid, & 7.022 & 1.23 \\
3-methylbutyl ester & & \\
Gamma-terpinene & 7.342 & 1.31 \\
L-Linalool & 8.636 & 0.3 \\
$\beta$-Linalool & 8.746 & 0.34 \\
Hexyl propionate & 8.813 & 0.35 \\
Hexyl butanoate & 11.941 & 25.98 \\
Spiro [2.5] octane & 12.03 & 2.49 \\
Capraldehyde & 12.14 & 0.28 \\
Pentylcyclopropane & 12.505 & 12.77 \\
Octyl 2-methylbuyrate & 13.246 & 14.37 \\
Decyl isobutyrate & 16.596 & 2.76 \\
Vinyl cyclohexane & 17.535 & 3 \\
Octyl isobutyrate & 18.11 & 17.82 \\
2-(aminomethyl) butanoic & 23.682 & 1.66 \\
acid & & \\
Angelicin & 28.557 & 0.35 \\
Octyl caprylate & 28.911 & 0.24 \\
Total & & 92.96 \\
\hline EO Essential & & \\
\hline & &
\end{tabular}

$\mathrm{EO}=$ Essential oil, $H$. persicum $=$ Heracleum persicum, $\mathrm{GC} / \mathrm{MS}=$ Gas chromatography/mass spectrometry that growth inhibition diameters of $\mathrm{EO}(10 \mathrm{mg} / \mathrm{mL})$ against $L$. monocytogenes were $6.7 \pm 0.15 \mathrm{~mm}$. The inhibition zone for ampicillin, as control positive, was $28.2 \pm 0.25$ and $17.4 \pm 0.45 \mathrm{~mm}$ for each of the treatments, respectively. Both MIC and MBC values of the EO were $2.5 \mathrm{mg} / \mathrm{mL}$ against $L$. monocytogenes. MIC and $\mathrm{MBC}$ of nisin against $L$. monocytogenes were 200 and $300 \mathrm{IU} / \mathrm{mL}$ by both methods. Growth inhibition zone of L. acidophilus was $13.2 \pm 0.15 \mathrm{~mm}$ by agar spot test.

Results of FIC values of $H$. persicum EO and nisin against tested bacteria are also shown in Table-3.

\section{Antibacterial effect of the EO in combination with $L$. acidophilus and nisin against $L$. monocytogenes in Iranian white cheese}

Results of the effect of $H$. persicum EO, L. acidophilus, and nisin on the growth of L. monocytogenes during the storage of the Iranian white cheese are shown in Tables-4 and 5. Results indicated that, in the control group, bacterial counts reached to $8.10 \pm 0.04$ $\log \mathrm{CFU} / \mathrm{g}$ at the end of the ripening period (day 60). All the treatments inhibited microbial growth when compared to the control $(\mathrm{p}<0.05)$.

\section{Chemical analysis}

Fat, protein and dry matter contents of the treatments were evaluated at the end of the storage period. In this respect, no significant difference was observed among different treatments, and all of them were in acceptable range.

\section{pH changes}

The $\mathrm{pH}$ of the treatments was evaluated on days $0,3,7,15,30$, and 60 . The average $\mathrm{pH}$ of the milk used for the cheese production was equivalent to 6.75 on the $1^{\text {st }}$ day. On days 15 and 60 of storage, $\mathrm{pH}$ showed a decreasing trend, such that it reached to 4.98 and 4.74 in the control group. $\mathrm{pH}$ changes were significantly different in samples containing 400 and $800 \mathrm{IU} / \mathrm{mL}$ nisin and samples containing higher concentrations $\left(10^{12}\right)$ of probiotics compared to the control at the end of the storage period.

\section{Sensory analysis of Iranian white cheese in different treatments}

Treatments containing $10^{9} \mathrm{~L}$. acidophilus showed the best acceptable taste, while the worst result was observed in treatments with $200 \mathrm{IU} / \mathrm{mL}$ nisin and $10 \mathrm{mg} / \mathrm{mL} \mathrm{H}$. persicum $\mathrm{EO}$ and treatments containing $800 \mathrm{IU} / \mathrm{mL}$ nisin $+10 \mathrm{mg} / \mathrm{mL}$ H. persicum EO (data not shown here).

\section{Discussion}

Chemical substances such as secondary metabolites in plants, having bioactive and biochemical properties, are used in many different industries such as pharmaceutical, chemical, cosmetics, and food industry [21]. In addition to EOs and plant extracts, probiotics and bacteriocins are also natural preservatives that have attracted the attention of consumers and food manufacturers in recent decades. 
Available at www.veterinaryworld.org/Vol.12/January-2019/13.pdf

Table-3: FIC values of $H$. persicum EO $(\mu \mathrm{g} / \mathrm{mL})$ and nisin $(\mathrm{IU} / \mathrm{mL})$ against $L$. monocytogenes.

\begin{tabular}{|c|c|c|c|c|c|c|c|}
\hline \multirow[t]{2}{*}{ Microorganism } & \multirow[t]{2}{*}{ FICI } & \multicolumn{3}{|c|}{ Nisin } & \multicolumn{3}{|c|}{ Essential oil } \\
\hline & & FIC & MICc & MIC $^{a}$ & FIC & $M^{\prime C}$ & MICa \\
\hline L. monocytogenes & $0.4+5.0$ & 0.5 & 2.65 & 5.3 & 0.4 & 1000 & 2500 \\
\hline
\end{tabular}

aSingle antibacterial agent, ${ }^{c}$ Combination of antibacterial agents. FICI=Fractional inhibitory concentration index, $L$. monocytogenes =Listeria monocytogenes, $H$. persicum $=$ Heracleum persicum, EO=Essential oil, MIC=Minimum inhibitory concentration

Table-4: Antimicrobial results (mean \pm SD) of single treatments against $L$. monocytogenes viable cell count during 60 days of storage in Iranian white cheese.

\begin{tabular}{|c|c|c|c|c|c|c|c|c|}
\hline \multirow[t]{2}{*}{ Day/Treatments } & \multicolumn{7}{|c|}{ Incubation time (days) } & \multirow[t]{2}{*}{ p-value* } \\
\hline & $\begin{array}{c}0 \\
\text { Mean } \pm \text { SD }\end{array}$ & $\begin{array}{c}3 \\
\text { Mean } \pm \text { SD }\end{array}$ & $\begin{array}{c}7 \\
\text { Mean } \pm \text { SD }\end{array}$ & $\begin{array}{c}15 \\
\text { Mean } \pm \text { SD }\end{array}$ & $\begin{array}{c}30 \\
\text { Mean } \pm \text { SD }\end{array}$ & $\begin{array}{c}45 \\
\text { Mean } \pm \text { SD }\end{array}$ & $\begin{array}{c}60 \\
\text { Mean } \pm \text { SD }\end{array}$ & \\
\hline $\mathrm{T} 1$ & $3.4(0.1)^{a}$ & $5.5(0.09)^{b}$ & $6.6(0.02)^{c}$ & $7.9(0.009)^{d}$ & $7.4(0.03)^{\mathrm{e}}$ & $7.7(0.02)^{f}$ & $8.1(0.05)^{g}$ & 4 \\
\hline $\mathrm{T} 2$ & $3.2(0.17)^{a}$ & $5.2(0.11)^{b}$ & $6.4(0.06)^{c}$ & $7.1(0.03)^{d}$ & $7.3(0.02)^{\mathrm{e}}$ & $7.7(0.02)^{f}$ & $7.9(0.02)^{g}$ & 01 \\
\hline T3 & $3.3(0.05)^{a}$ & $4.9(0.05)^{b}$ & $6.1(0.01)^{c}$ & $6.6(0.04)^{d}$ & $6.8(0.08)^{d}$ & $7.5(0.07)^{\mathrm{e}}$ & $7.4(0.06)^{\mathrm{e}}$ & $<0.001$ \\
\hline $\mathrm{T} 4$ & $3.1(0.14)^{a}$ & $3.7(0.04)^{b}$ & $4.4(0.10)^{c}$ & $5.5(0.04)^{d}$ & $5.6(0.02)^{\mathrm{e}}$ & $5.4(0.04)^{f}$ & $5.3(0.07)^{f}$ & $<0.001$ \\
\hline T5 & $3.2(0.06)^{a}$ & $3.8(0.07)^{b}$ & $4.2(0.17)^{\mathrm{b}}$ & $4.8(0.10)^{\mathrm{b}}$ & $5.3(0.04)^{c}$ & $5.1(0.03)^{d}$ & $5(0.06)^{e}$ & $<0.001$ \\
\hline T6 & $3.1(0.17)^{a}$ & $5.4(0.15)^{b}$ & $6.5(0.07)^{c}$ & $7.2(0.01)^{d}$ & $7.5(0.01)^{\mathrm{e}}$ & $7.7(0.05)^{f}$ & $7.9(0.01)^{\mathrm{g}}$ & $<0.001$ \\
\hline T7 & $3.1(0.15)^{a}$ & $5.4(0.03)^{b}$ & $5.3(0.08)^{b}$ & $5.1(0.04)^{\mathrm{b}}$ & $4.9(0.07)^{\mathrm{b}}$ & $4.7(0.08)^{c}$ & $4.6(0.04)^{c}$ & $<0.001$ \\
\hline T8 & $3.1(0.15)^{a}$ & $4.9(0.04)^{b}$ & $5.1(0.10)^{\mathrm{b}}$ & $4.9(0.04)^{\mathrm{b}}$ & $4.8(0.08)^{\mathrm{b}}$ & $4.6(0.05)^{b}$ & $4.4(0.10)^{c}$ & $<0.001$ \\
\hline
\end{tabular}

*p value for difference with control. The same letters do not differ statistically by the Tukey test $(p<0.05)$

Table-5: Antimicrobial results of combination treatments against L. monocytogenes viable cell count during 60 days of storage in Iranian white cheese.

\begin{tabular}{|c|c|c|c|c|c|c|c|c|}
\hline \multirow[t]{2}{*}{ Day/Treatments } & \multicolumn{7}{|c|}{ Incubation time (days) } & \multirow[t]{2}{*}{ p-value* } \\
\hline & $\begin{array}{c}0 \\
\text { Mean } \pm S D\end{array}$ & $\begin{array}{c}3 \\
\text { Mean } \pm \text { SD }\end{array}$ & $\begin{array}{c}7 \\
\text { Mean } \pm S D\end{array}$ & $\begin{array}{c}15 \\
\text { Mean } \pm \text { SD }\end{array}$ & $\begin{array}{c}30 \\
\text { Mean } \pm \text { SD }\end{array}$ & $\begin{array}{c}45 \\
\text { Mean } \pm \text { SD }\end{array}$ & $\begin{array}{c}60 \\
\text { Mean } \pm \text { SD }\end{array}$ & \\
\hline T9 & $3.3(0.06)^{a}$ & $3.8(0.03)^{b}$ & $4.5(0.07)^{c}$ & $5.2(0.02)^{d}$ & $5.7(0.01)^{e}$ & $5.5(0.03)^{f}$ & $5.4(0.03)^{g}$ & $<0.001$ \\
\hline T10 & $3.1(0.15)^{a}$ & $3.7(0.12)^{a}$ & $4.6(0.05)^{b}$ & $4.9(0.05)^{c}$ & $5.6(0.03)^{d}$ & $5.4(0.03)^{e}$ & $5.3(0.04)^{f}$ & $<0.001$ \\
\hline T11 & $3.2(0.17)^{a}$ & $3.6(0.05)^{a}$ & $4.4(0.10)^{b}$ & $4.9(0.07)^{c}$ & $5.5(0.04)^{d}$ & $5.2(0.05)^{\mathrm{e}}$ & $5.1(0.01)^{\mathrm{e}}$ & $<0.001$ \\
\hline T12 & $3.3(0.05)^{a}$ & $3.9(0.05)^{b}$ & $4.5(0.07)^{c}$ & $4.9(0.04)^{d}$ & $5.5(0.04)^{e}$ & $5.3(0.04)^{f}$ & $5.2(0.04)^{f}$ & $<0.001$ \\
\hline T13 & $3.2(0.07)^{a}$ & $3.7(0.08)^{b}$ & $4.3(0.10)^{c}$ & $4.9(0.00)^{d}$ & $5.2(0.02)^{e}$ & $5.1(0.07)^{e}$ & $4.9(0.06)^{e}$ & $<0.001$ \\
\hline T14 & $3.1(0.17)^{a}$ & $3.7(0.15)^{a}$ & $4.2(0.17)^{\mathrm{a}}$ & $4.9(0.07)^{\mathrm{b}}$ & $5.2(0.05)^{\mathrm{b}}$ & $5(0.06)^{\mathrm{b}}$ & $4.8(0.04)^{c}$ & $<0.001$ \\
\hline T15 & $3.1(0.15)^{a}$ & $5.3(0.08)^{b}$ & $6.6(0.02)^{c}$ & $7.1(0.02)^{d}$ & $7.6(0.11)^{\mathrm{e}}$ & $7.7(0.02)^{e}$ & $7.8(0.00)^{f}$ & $<0.001$ \\
\hline T16 & $3.1(0.15)^{a}$ & $5.2(0.04)^{b}$ & $6.5(0.02)^{c}$ & $7.2(0.01)^{d}$ & $7.5(0.09)^{f}$ & $7.6(0.06)^{f}$ & $7.7(0.02)^{g}$ & $<0.001$ \\
\hline T17 & $3.3(0.05)^{a}$ & $5.1(0.00)^{b}$ & $6.6(0.02)^{c}$ & $7.3(0.02)^{d}$ & $7.6(0.08)^{\mathrm{e}}$ & $7.7(0.04)^{\mathrm{e}}$ & $7.8(0.01)^{f}$ & 0.01 \\
\hline T18 & $3.2(0.05)^{a}$ & $5.2(0.07)^{b}$ & $5.2(0.03)^{b}$ & $5.1(0.04)^{c}$ & $4.9(0.07)^{c}$ & $4.8(0.01)^{c}$ & $4.7(0.04)^{c}$ & $<0.001$ \\
\hline T19 & $3.2(0.06)^{a}$ & $5.1(0.19)^{b}$ & $5.2(0.03)^{b}$ & $5.2(0.02)^{c}$ & $4.9(0.17)^{c}$ & $4.8(0.01)^{c}$ & $4.7(0.04)^{c}$ & $<0.001$ \\
\hline T20 & $3.5(0.06)^{a}$ & $5.3(0.08)^{b}$ & $5.3(0.02)^{b}$ & $5.1(0.03)^{c}$ & $4.8(0.04)^{d}$ & $4.6(0.08)^{d}$ & $4.5(0.06)^{d}$ & $<0.001$ \\
\hline T21 & $3.4(0.05)^{a}$ & $4.9(0.04)^{\mathrm{b}}$ & $5(0.03)^{b}$ & $4.8(0.08)^{\mathrm{c}}$ & $4.6(0.05)^{c}$ & $4.2(0.17)^{d}$ & $4.1(0.12)^{d}$ & $<0.001$ \\
\hline T22 & $3.4(0.03)^{a}$ & $4.8(0.06)^{b}$ & $5.1\left(0.05^{c}\right.$ & $4.8(0.06)^{d}$ & $4.7(0.08)^{d}$ & $4.4(0.10)^{e}$ & $4.1(0.16)^{f}$ & $<0.001$ \\
\hline T23 & $3.3(0.10)^{a}$ & $4.9(0.05)^{b}$ & $5(0.03)^{c}$ & $4.7(0.04)^{d}$ & $4.5(0.07)^{\mathrm{e}}$ & $4.2(0.17)^{\mathrm{e}}$ & $3.9(0.02)^{\mathrm{e}}$ & $<0.001$ \\
\hline T24 & $3.2(0.20)^{a}$ & $5.6(0.05)^{b}$ & $6.5(0.01)^{c}$ & $7.2(0.01)^{d}$ & $7.6(0.07)^{e}$ & $7.8(0.01)^{f}$ & $8.1(0.04)^{g}$ & $<0.001$ \\
\hline
\end{tabular}

*p value for difference with control. The same letters do not differ statistically by the Tukey test $(p<0.05)$

In the present study, the entire aerial parts of H. persicum were analyzed, and four components of hexyl butanoate $(25.98 \%)$, octyl isobutyrate $(17.73 \%)$, n-octyl-2 methyl- butyrate $(14.37 \%)$, and pentyl cyclopropane $(12.77 \%)$ were identified as the main constituents of the EO. Despite the differences with other studies regarding EO compositions [22-24], aliphatic esters were the main constituents of the H. persicum EOs. Climate, time of harvest, storage time, distillation method, and genetic differences are effective on the compositions and concentrations of plant EO [25]. Since EO application in foods is generally recognized as safe including $H$. persicum [26] and also based on the components detected in the GC analysis, this EO was chosen in this study.
To the best of our knowledge, there is only one study focusing on the antibacterial effect of the $H$. persicum $\mathrm{EO}$, describing that $H$. persicum EO has some antimicrobial effects against Escherichia coli and Campylobacter jejuni by agar disc diffusion and microdilution assays [27]. The antimicrobial effect of Heracleum thomsonii against fungi, and Gram-positive and Gram-negative bacteria was also evaluated, and a strong antibacterial effect of $H$. thomsonii was reported, which could be due to the presence of significant amounts of different compositions such as "nerol" (87.9\%) and "neryl acetate" (62.51\%) [28].

MIC and MBC values of nisin for L. monocytogenes were 5.3 and $6.9 \mathrm{mg} / \mathrm{mL}$, respectively.

A previous study showed that nisin had antimicrobial effect on L. monocytogenes in BHI broth; 
although antibacterial effect of nisin on L. monocytogenes is strain dependent [29]. Murdock et al. [30] reported MIC value of nisin against $L$. monocytogenes as $250 \mathrm{IU} / \mathrm{mL}$. Different reported MIC values for nisin might be due to the different applied media; for example, in the Tryptose Agar medium, microorganisms show higher MIC value because the presence of high amounts of divalent cations causes more resistance to nisin [30]. Nisin creates holes in the membrane cytoplasm and disables the proton motive force which stops the absorption of amino acids and small metabolites [31].

Low stability of nisin at higher $\mathrm{pH}$ values has restricted its application in certain food products [32]. Therefore, nisin in combination with other natural antimicrobial is an innovative approach for its usage. According to the results of this study, combinational use of nisin with $H$. persicum EO showed stronger effects against $L$. monocytogenes than individual usage. There are no available published data about the application of nisin in combination with $H$. persicum EO against pathogenic bacteria, but there are reports about the use of nisin with other plant EOs and extracts. In a former study, the effects of organic extracts of garlic and nisin were evaluated on six strains of L. monocytogenes in a model broth medium, and a synergistic bactericidal effect was observed [33].

Increasing concentration of nisin (T21, T22, and T23) could significantly decrease the number of L. monocytogenes $(\mathrm{p}<0.05)$, but the use of nisin at higher doses might be high risk because of the development of resistant strains against bacteriocins [34], so it is necessary to use other natural preservatives such as EOs or probiotic bacteria to use lesser amounts of nisin.

The results of the effect of $L$. acidophilus against L. monocytogenes suggested a suitable inhibitory effect of this probiotic against tested pathogenic bacteria. In this regard, Strus et al. [35] reported anti-pathogenic impact of Lactobacillus strains against anaerobic pathogens of gastrointestinal tract. Niel et al. [36] reported the treatment of neonatal diarrhea with probiotic Lactobacillus and reported signs of improvement. Ogunbanw et al. [37] studied the antimicrobial activity of $L$. plantarum and $L$. brevis by well diffusion method, and these organisms exhibited preventive activities against E. coli NCTC10418 and Enterococcus faecalis EF1. Products of the probiotic bacteria such as acetic acid and lactic acid prevent the growth of pathogens by changing the $\mathrm{pH}$ value as well as inhibition of adhesion and invasion to the epithelial cell by increasing the production of intestinal mucins [38]. L. acidophilus also showed antimicrobial potency against $L$. monocytogenes through creating growth inhibition zones in an agar spot test.

Despite strong antimicrobial activity of EOs against pathogenic and food spoilage microorganisms, the practical use of EOs in food production industry has been limited, due to adverse flavor changes [39]. In this study, a combination of $10^{12} \mathrm{CFU} / \mathrm{g}$ L. acidophilus with $H$. persicum $\mathrm{EO}$ at the concentration of $2.5 \mathrm{mg} / \mathrm{mL}$ (T12) showed remarkable sensorial and also antibacterial results in Iranian white cheese.

Lactic acid bacteria, compared to other gram-positive bacteria, are highly resistant against EOs [40]. Hence, the effect of nisin and L. acidophilus on $\mathrm{pH}$ and cheese production process should be taken into consideration. All concentrations of the EO and lower levels of probiotic had no significant effect on $\mathrm{pH}$ value of the samples, while significant changes of $\mathrm{pH}$ value were observed in treatments containing 400 and $800 \mathrm{IU} / \mathrm{mL}$ of nisin and treatments containing higher levels of probiotic (data not shown here). The sensitivity of lactic acid bacteria against nisin is one of the logical reasons for changes in $\mathrm{pH}$ of treatments, containing higher concentrations of nisin (400 and $800 \mathrm{IU} / \mathrm{mL}$ ). L. acidophilus can also produce bacteriocins, affecting starter bacteria and modifying the cheese ripening process. In a study by Kykkidou et al. [41], on Galotyri (Greek local soft cheese), lactic acid bacteria were sensitive to nisin, and along with the reduction of spoilage bacteria, the number of Lactobacillus and Lactococcus strains was also reduced in cheese.

\section{Conclusion}

According to the obtained results, a combination of low concentration of H. persicum EO, L. acidophilus, and nisin can be suggested as flavoring agents and natural preservative(s) in the cheese production industry.

\section{Authors' Contributions}

$\mathrm{AR}$ and $\mathrm{BJ}$ carried out the experiment. AA wrote the manuscript. MA and $\mathrm{MH}$ supervised the project. $\mathrm{AE}$ conceived the original idea and supervised the project. All authors read and approved the final manuscript.

\section{Acknowledgments}

The authors would like to thank Urmia University, Urmia, Iran, for financial support (Thesis No. d2-36).

\section{Competing Interests}

The authors declare that they have no competing interests.

\section{References}

1. Spillmann, M.D., Siegrist, M. and Keller, C. (2011) Attitudes toward chemicals are associated with preference for natural food. Food. Qual. Prefer., 22(1): 149-156.

2. Chouhan, S., Sharma, K. and Guleria, S. (2017) Antimicrobial activity of some essential oils present status and future perspectives. Medicines, 4(3): 58 .

3. Vergis, J., Gokulakrishnan, P., Agarwal, R.K. and Kumar, A. (2015) Essential oils as natural food antimicrobial agents: A review. Crit. Rev. Food. Sci. Nutr., 55(10): 1320-1323.

4. Bahadori, M.B., Dinparast, L. and Zengin, G. (2016) The genus Heracleum: A comprehensive review on its phytochemistry, pharmacology, and ethnobotanical values as a useful herb. Compr. Rev. Food. Sci. Food Saf., 15(6): 1018-1039.

5. Anbaran, M.F., Bazargani, M.M. and Rohloff, J. (2018) 
Large scale geographical mapping of essential oil volatiles in Heracleum (Apiaceae): Identification of novel compounds and unraveling cryptic variation. Chem. Biodivers., 15(9): e1800230.

6. Abdollahzadeh, E., Rezaei, M. and Hosseini, H. (2014) Antibacterial activity of plant essential oils and extracts: The role of thyme essential oil, nisin, and their combination to control L. monocytogenes inoculated in minced fish meat. Food Control, 35(1): 177-183.

7. Norhan, M.W., Pool, S.E., Deeth, H.C. and Dykes, G.A. (2012) Effects of nisin, EDTA and salts of organic acids on L. monocytogenes, Salmonella and native microflora on fresh vacuum packaged shrimps stored at $4 \mathrm{C}$. Food Microbiol., 31(1): 43-50.

8. Amara, A.A. and Shibl, A. (2015) Role of probiotics in health improvement, infection control and disease treatment and management. Saudi Pharm. J., 23(2): 107-114.

9. Miguel, G., Simoes, M., Figueiredo, A., Barroso, J., Pedro, L. and Carvalho, L. (2004) Composition and antioxidant activities of the essential oils of Thymus caespititius, Thymus camphoratus and Thymus mastichina. Food Chem., 86(2): 183-188.

10. Burt, S. (2004) Essential oils: Their antibacterial properties and potential applications in foods a review. Int. J. Food Microbiol., 94(3): 223-253.

11. Adams, R.P. (2001) Identification of Essential oil Components by Gas Chromatography/Mass Spectroscopy. Allured Publishing Corporation, Illinois.

12. Ehsani, A., Hashemi, M., Naghibi, S.S., Mohammadi and, S., Sadaghiani, S.K. (2016) Properties of Bunium persicum essential oil and its application in Iranian white cheese against L. monocytogenes and Escherichia coli O157: H7. J. Food Saf., 36(4): 563-570.

13. Chen, H. and Hoover, D. (2003) Bacteriocins and their food applications. Compr. Rev. Food. Sci. Food Saf., 2(3): 82-100.

14. Eliopoulos, G.M. (1996) In: Lorian, V., editor. Antimicrobial Combinations, in Antibiotics in Laboratory Medicine. $4^{\text {th }} \mathrm{ed}$. Williams and Wilkins Co., Baltimore, USA. p330-396.

15. Schwalbe, R., Moore, L.S. and Goodwin, A.C. (2007) Antimicrobial Susceptibility Testing Protocols. CRC Press, New York.

16. Pouch, D.F. and Ito, K. (2001) Compendium of Methods for the Microbiological Examination of Foods. American Health Association, Washington DC.

17. Ehsani, A., Hashemi, M., Afshari, A. and Aminzare, M. (2018) Probiotic white cheese production using coculture with Lactobacillus species isolated from traditional cheeses. Vet. World, 11(5): 726-730.

18. Ardö, Y. and Polychroniadou, A. (1999) Laboratory Manual for Chemical Analysis of Cheese. Publications Office, Luxembourg.

19. Sadler, G.D. and Murphy, P.A. (2003) pH and Titratable Acidity. Food Analysis. Springer, New York. p207-25.

20. Lim, J. (2011) Hedonic scaling: A review of methods and theory. Food Qual. Prefer. 22(8): 733-747.

21. Nabavi, S.F., Lorenzo, A.D., Izadi, M., Sánchez, E.S., Daglia, M. and Nabavi, S.M. (2015) Antibacterial effects of cinnamon: From farm to food, cosmetic and pharmaceutical industries. Nutrients, 7(9): 7729-7748.

22. Taniguchi, M., Yokota, O., Shibano, M., Wang, N.H. and Baba, K. (2005) Four coumarins from Heracleum yunngningense. Chem. Pharm. Bull., 53(6): 701-704.

23. Miladinović, L. (2013) Antibacterial activity of the essential oil of Heracleum sibiricum. Natl. Prod. Commun., 8(9): 1309-1311.

24. Boroujeni, L.S., Hojjatoleslami, M., Keramat, J. and Pirbalouti, A.G. (2013) Antioxidant activity of essential oil of Heracleum lasiopetalum fruits on chemical properties of potato chips. J. Herb. Drugs, 3(4): 249-256.

25. Jurado, F.R., Vega, A.F., Corona, N.R., Palou, E. and Malo, A.L. (2015) Essential oils: Antimicrobial activities, extraction methods, and their modeling. Food Eng. Rev., 7(3): 275-297.

26. Sharififar, S.,Pournourmohammadi, R., Rastegarianzadeh, O., Ranjbaran, A., Purhemmaty, A. and Sharififar, F. (2010) Immunomodulatory activity of aqueous extract of Heracleum persicum Desf. In mice. Iran. J. Pharm. Res., 8(4): 287-292.

27. Pirbalout, A. (2009) Medicinal plants used in Chaharmahal and Bakhtyari districts of Iran. Herba Pol., 55(2): 69-77.

28. Guleria, S., Saini, R., Jaitak, V., Kaul, V., Lal, B., Rahi, P., Gulatiand, A. and Singh, B. (2011) Composition and antimicrobial activity of the essential oil of Heracleum thomsonii (Clarke) from the cold desert of the western Himalayas. Natl. Prod. Res., 25(13): 1250-1260.

29. Jamuna, M., Babushaand, S. and Jeevaratnam, K. (2005) Inhibitory efficacy of nisin and bacteriocins from Lactobacillus isolates against food spoilage and pathogenic organisms in model and food systems. Food Microbiol., 22(5): 449-454.

30. Murdock, C., Cleveland, J., Matthews, K. and Chikindas, M. (2007) The synergistic effect of nisin and lactoferrin on the inhibition of L. monocytogenes and Escherichia coli O157: H7. Lett. Appl. Microbiol., 44(3): 255-261.

31. Wenzel, M., Chiriac, A.I., Otto A., Zweytick, D., May, C., Schumacher, C., Gust, R., Albada, H.B., Penkova, M., Krämer, U. and Erdmann, R. (2014) Small Cationic Antimicrobial Peptides Delocalize Peripheral Membrane Proteins. Proceedings of the National Academy of Sciences, 201319900.

32. Boziaris, I. and Nychas, G. (2006) Effect of nisin on growth boundaries of $L$. monocytogenes Scott A, at various temperatures, $\mathrm{pH}$ and water activities. Food Microbiol., 23(8): 779-784.

33. Singhm, B., Falahee, M.B. and Adams, M.R. (2001) Synergistic inhibition of L. monocytogenes by nisin and garlic extract. Food. Microbiol., 18(2): 133-139.

34. Ettayebi, K., Yamaniand, J.E. and Hassani, B.D. (2000) Synergistic effects of nisin and thymol on antimicrobial activities in L. monocytogenes and Bacillus subtilis. FEMS Microbiol. Lett., 183(1): 191-195.

35. Strus, M., Pakosz, K., Gościniak, H., Mordarska, A.P., Rozynek, E., Pituch, H., Mikołajczyk, F.M. and Heczko, H. (2000) Antagonistic activity of Lactobacillus bacteria strains against anaerobic gastrointestinal tract pathogens (Helicobacter pylori, Campylobacter coli, Campylobacter jejuni, Clostridium difficile). Med. Dosw Mikrobiol., 53(2): 133-142.

36. Niel, C.V., Feudtner, C., Garrison, M.M. and Christakis, D.A. (2002) Lactobacillus therapy for acute infectious diarrhea in children: A meta-analysis. Pediatrics, 109(4): 678-684.

37. Ogunbanwo, S., Sanniand, A. and Onilude, A. (2003) Characterization of bacteriocin produced by Lactobacillus plantarum $\mathrm{F} 1$ and Lactobacillus brevis OG1. Afr. J. Biotechnol., 2(8): 219-227.

38. Servin, A.L. (2004) Antagonistic activities of lactobacilli and bifidobacteria against microbial pathogens. FEMS Microbiol. Rev., 28(4): 405-440.

39. Massilia, R.M., Melgar, J.M., Fortuny, R.S. and Belloso, O.M. (2009) Control of pathogenic and spoilage microorganisms in fresh-cut fruits and fruit juices by traditional and alternative natural antimicrobials. Compr. Rev. Food Sci. Food Saf., 8(3): 157-80.

40. Perricone, M., Arace, E., Corbo, M.R., Sinigaglia, M. and Bevilacqua, A. (2015) Bioactivity of essential oils: A review on their interaction with food components. Front Microbiol., 6: 76.

41. Kykkidou, S., Pournis, N., Kostoula, O.K. and Savvaidis, I.N. (2007) Effects of treatment with nisin on the microbial flora and sensory properties of a Greek soft acid-curd cheese stored aerobically at 4 C. Int. Dairy J., 17(10): 1254-1258. 